\title{
ANTECEDENTS THAT INFLUENCE PARTICIPATORY BUDGETARY CONFIGURATION AND ITS EFFECTS ON VERTICAL INFORMATION SHARING AND MANAGERIAL PERFORMANCE
}

\author{
Vinicius Costa da Silva Zonatto \\ Micheli Aparecida Lunardi ${ }^{2}$ \\ Larissa Degenhart ${ }^{3}$
}

\begin{abstract}
The purpose of this study was to examine the effects of budget participation in the sharing of vertical information and in the performance of controllers with budgetary responsibility in companies operating in Brazil, observing the effects of variables antecedent to the budget process, related to actions and behavior of the leader. In order to respond to the objective, a descriptive research was carried out by means of a survey and a quantitative approach to the data analysis, based on a sample of 316 respondents who perform the role of controller, manager or controllership coordinator.The theoretical relations investigated in this research were tested using the modeling technique of structural equations. The results showed a strong relationship between leadership style and incentive of budget participation. Positive, statistically significant relationship was found between encouraging participation and budget participation, as well as between budget participation and information sharing. These results reveal that the leader's incentive for controllers to participate in the budget processes in their organizations constitutes an important antecedent for the budget participation and its consequent effects on the managerial performance. The positive influence of vertical information sharing on performance reveals that this condition is a determinant for a better managerial performance of the controllers participating in the research. It is concluded that the antecedents of budget participation, related to the leadership style and the incentive to participate, contribute to the understanding of the budget configuration adopted by the companies and its effects on the managerial performance of controllers, which is enhanced whenthe occurrence ofvertical information sharing.
\end{abstract}

Keywords: Leadership Style;Incentive of Budget Participation; Budget Participation; Vertical Information Sharing; Managerial Performance.

' viniciuszonatto@gmail.com - Universidade Federal de Santa Maria-RS. Brasil. https://orcid.org/0000-0003-0823-6774
2 micheli.lunardi@yahoo.com.br - Universidade Regional de Blumenau-SC. Brasil. https://orcid.org/0000-0003-0622-928X

lari_ipo@hotmail.com - Universidade Federal de Santa Maria. https://orcid.org/0000-0003-0651-8540 


\section{ANTECEDENTES QUE INFLUENCIAM A CONFIGURAÇÃO ORCCAMENTÁRIA PARTICIPATIVA E SEUS EFEITOS ${ }^{3} N O$ COMPARTILHAMENTO DE INFORMAÇÃO VERTICAL E NO DESEMPENHO GERENCIAL}

Resumo: Este estudo teve por objetivo examinar os efeitos da participação orçamentária no compartilhamento de informação vertical e no desempenho de controllers com responsabilidade orçamentária em empresas que atuam no Brasil, observando-se os efeitos de variáveis antecedentes ao processo orçamentário, relacionadas a ações e comportamento do líder.Para responder ao objetivo desenvolveu-se uma pesquisa descritiva, realizada por meio de um levantamento e abordagem quantitativa para a análise dos dados, a partir de uma amostra de 316 respondentes que exercem a função de controller, gerente ou coordenador de controladoria. As relações teóricas investigadas nesta pesquisa foram testadas a partir da técnica de modelagem de equações estruturais. Os resultados encontrados demonstraram uma forte relação entre o estilo de liderança e o incentivo à participação orçamentária. Relação positiva, estatisticamente significativa, foi encontrada entre o incentivo à participação e a participação orçamentária, bem como entre a participação orçamentária e o compartilhamento de informações. Estes resultados revelam que o incentivo do líder à participação dos controllers nos processos orçamentários em suas organizações, constitui-se um antecedente importante para a participação orçamentária e seus efeitos consequentes sobre o desempenho gerencial. A influência positiva do compartilhamento de informação vertical no desempenho, revela que esta condição é determinante para que ocorra um melhor desempenho gerencial dos controllers participantes da pesquisa. Conclui-se que os antecedentes a participação orçamentária, relacionados ao estilo de liderança e o incentivo a participação, contribuem para o entendimento da configuração orçamentária adotada pelas empresas e seus efeitos no desempenho gerencial de controllers, que é potencializado quando da ocorrência de compartilhamento de informações verticais.

Palavras-chave: Estilo de Liderança; Incentivo à Participação Orçamentária; Participação Orçamentária; Compartilhamento de Informação Vertical; Desempenho Gerencial. 


\section{INTRODUCTION}

$\mathrm{T}$

he aspects of managerial accounting are implied in the budget context, since it has several purposes,

such as planning and coordinating activities, allocating resources, motivating employees (Covaleski, Evans III, Luft\& Shields, 2007). In this sense, several organizations encourage the participation of individuals in the budget processes, that is, they seek the involvement of the employees in the definitions of the goals and budgetary objectives and their influence on the establishment of the budgets of their units, which consequently presents impacts on the performance of the individual at work (Covaleski et al., 2007; Shields \& Shields, 1998;Milani, 1975).

However, the initial literature that dealt with the relationship between budget participation and managerial performance presented contradictory results, for example, positive(Zonatto, 2014; Noor \& Othman, 2012; Covaleski et al., 2007; Birnberg, Luft\& Shields, 2006; Parker \&Kyj, 2006; Shields \& Shields, 1998; Kren, 1992; Brownell, 1982; Chenhall\& Brownell, 1988), negative(Almasi, Palizdar\&Parsian, 2015; Etemadi, Dilami, Bazaz\&Parameswaran, 2009) and non-significant (Macinati, Bozzi\& Rizzo, 2016; Milani, 1975), evidences were found, which stimulates the development of other research in relation to the behavioral approach to accounting (Birnberg, Luft\& Shields, 2006; Covaleski et al., 2007) and the inclusion of explanatory variables for this relationship, such as the sharing of vertical information and the use of antecedent variables that explain the participation of individuals in the budget processes, such as leadership style and incentive to budget participation (Derfuss, 2016).

Regarding the antecedent participation, the leadership style of the superiors can influence the behavior of the other individuals towards a goal (Pearce, Conger \& Locke, 2008; Otley\& Pierce, 1995;Fleishman \& Peters, 1962). Niemeyer and Cavazotte (2016) point out that leadership is the result of interaction between leaders and their subordinates and this relationship can turn into a high level of partnership. There is a link between the personality of managers and leaders and the management model of their organizations (Bianchi, Quishida\&Foron, 2017) and the leader plays an essential role in encouraging subordinates to participate in organizational processes, more specifically in this research the budget processes.

The management control procedures frequently used in organizations involve the participation of managers and their subordinates. Of these, we highlight the budget participation (Silva \& Gomes, 2011; Webb, 2002;Baiman\& Evans, 1983), in which a leader is involved and have influence over the determination as well as the realization of the budget (Covaleski et al., 2007; Shields \& Shields, 1998;Milani, 1975). Because it is a factor capable of influencing individuals at work, another potential antecedent capable of explaining possible differences in the way subordinate managers participate in this process, refers to the leader's incentive to participation, which refers to the extent that superiors seek the participation of subordinates during the budget process (Kyj\& Parker, 2008).

The participation of the managers in these managerial processes can contribute to the improvement of the work environment, which, consequently, tends to positively impact the performance of the individuals in the organization (Zonatto, 2014; Chong, Eggleton\& Leong, 2005). This is because budget participation allows managers to increase the sharing of information with their superiors, which enables improved communication between managerial levels (Baiman, 1990). According to Kyj and Parker (2008), budget participation occurs for a number of reasons, such as vertical information sharing, coordination among subunits of the organization, increased motivation, and employee satisfaction.According to Locke and Latham (1990), budget participation exists to share information between a superior and 
a subordinate. However, the behavioral approach in accounting (Covaleski et al., 2007) suggests that budget participation may exert different effects on individuals at work (Chong, Eggleton\& Leong 2005; Brownell, 1983).

Despite such evidence, there are reports of recent studies on the subject suggesting that only participating in the budget processes does not mean that the expected performance will be effectively achieved (Derfuss, 2016). This is because there are other intervening factors to this relationship, which can influence the predisposition of individuals in revealing or not private information. In this context, a challenge to organizations and their leaders refers to the identification of mechanisms that can create conditions for greater interaction between superiors and subordinates, from which both are willing to share relevant information about their work activities, so that the result of this participation, can positively influence the performance of the manager.

In this context, a research gap identified in the accounting literature deals with the analysis of such relationships from a broader theoretical perspective, observing the effects of antecedent variables that influence the organization's budgetary configuration (whether participatory or not) and their effects on performance(mediated by intervening variables in this process).In this research, the antecedents considered referring to the actions and behaviors of the leader, represented by the variables of leadership style and incentive to participation. As an important intervening variable to the effects of participation in performance, we have the sharing of vertical information, a variable present in the relationship established between senior and subordinate managers.

In this way, the guiding question of this research is: What is the effect of the budget participation in the vertical information sharing and the managerial performance? In this sense, the main objective of this study is to examine the effects of budgetary participation in the sharing of vertical information and in the managerial performance of controllers with budgetary responsibility in companies operating in Brazil, observing the antecedent effects that influence the participatory budgetary configuration and their influence on vertical information sharing and managerial performance.

Studies conducted from the behavioral approach to accounting have analytically modeled how the differences in information between a superior and a subordinate, or vertical information sharing, may affect the demand for budget participation in organizations(Kyj\& Parker, 2008; Nouri \& Parker, 1998; Shields \& Young 1993;Penno, 1984;Baiman\& Evans, 1983). According to Kyj and Parker (2008) and Shields and Young (1993), budget participation is used by leaders to learn about the local environment so that decisions such as resource allocation can be improved and incentives are designed for subordinates during the budget process. However, there are antecedents that may determine the occurrence of this participation.

In this sense, when analyzing these relationships from an integrated perspective, evaluating the effects of antecedents to budget participation and intervening variables (mediators) in their relationship with managerial performance, it becomes possible to identify the conditions in which asuperior and his subordinates can obtain greater vertical information sharing and better performance. Although many studies in the accounting area assume that budget participation leads to information sharing between superior and subordinates (Parker \&Kyj, 2006; Nouri \& Parker, 1998;Kren, 1992;Mia, 1988), their effects on managerial performance can occur indirectly (Dani, Zonatto \& Diehl, 2017; Derfuss, 2016), which reinforces the importance of the analysis proposed in this study.

The results of the study revealed a positive and significant association between leadership style and the incentive to participate in the budget.In addition, the incentive to budget participation has influenced the participation of subordinates in the budget processes.The research findings also showed that 
budget participation influences the sharing of vertical information, which potentiates the performance of controllers in budget activities.

Overall, the findings suggest that the way the leader conducts his work has positive impacts on the participation of individuals in budget processes, and this relationship is strengthened through the leader's encouragement for subordinates to participate in this process.From these results, it is denoted out that budget participation reinforces the sharing of information between superior and subordinates. Consequently, greater information sharing has a positive impact on managerial performance, which suggests that increasing organizational support through budget participation leads to greater sharing of information between superiors and their subordinates, which implies a better managerial performance.

Thus, it is opportune for organizations to direct efforts towards the development of proactive leaders and that aim at the active participation of subordinates in the budget processes, since these positive attitudes generate a greater participation of these individuals in this process.Consequently, these managers will share more information, which will positively impact the planning, investigation, coordination, evaluation, supervision, selection, negotiation and representation (management performance) activities.

In the view of Shields and Shields (1998), studies based on psychological theories approach that the cognitive mechanism presupposes that the process of budgetary participation improves the performance of the subordinate, thus increasing the quality of budget decisions as a result of information sharing vertical. However, it is the leader's actions that determine how this participation will occur, whether actively or passively (Zonatto, 2014). In this context, as theoretical contributions of this research, we seek to provide evidence of the effects of antecedents to budget participation, in the budget configuration of organizations (whether participatory or not), so that their consequences can be understood in the vertical informationsharing and in the process of managerial performance of controllers.

\section{THEORETICAL MODEL OF ANALYSIS AND RESEARCH HYPOTHESES}

Several theoretical models have already been analyzed over the years in the budgetary context. Some recent studies, such as the models analyzed by Macinati, Bozzi and Rizzo (2016) and Almasi, Palizdar and Parsian (2015), which took into account intervening variables, in order to explain the relation between budgetary participation and managerial performance. However, in the configuration proposed in the research, no evidence was found, which stimulated the development of this study.

With regard to leadership style and incentive to budget participation, Argyris (1952) study found that managers express their leadership approach, in part, by how they use the budget system, which can impact the incentive to budgetary participation. Brownell (1983) points out that budget participation moderates the relationship between leadership style and work performance, suggesting a positive relationship between leadership style and the encouragement (subordinate)of budget participation.

Kyj and Parker (2008) and Brownell (1982) argue that leadership style positively influences the subordinate's incentive to budget share. Kyj and Parker (2008) suggest that superiors encourage subordinate participation during the budget process, depending on their leadership style. According to Fleishman and Harris (1962), managers who respect subordinates and develop relationships based on trust and open communication are likely to encourage subordinates to participate during the budget process (Kyj\& 
Parker, 2008). Thus, the first hypothesis to be tested in this research is the influence of leadership style on the incentive to subordinate budget participation: $\mathrm{H} 1$ - The leadership style is positively associated with the incentive to budget participation.

Employee engagement with the superior's leadership style can be transformed into the subordinate commitment to the organization (Wong-On-Wing, Guo \& Lui, 2010). In this way, leadership style helps to coordinate work routines and will result in the exchange of information between superior and subordinate, which indicates a positive relationship between superior leadership style and budget participation. Brownell (1983) demonstrated in his study evidence of positive relationships between leadership style and budget participation, as well as its effects on managerial performance.However, the study by Kyj and Parker (2008) did not identify a direct interaction between leadership style and participation in the budget. In this research, considering the predominant evidence found in the previous revisited studies, it is suggested that the style of leadership influences in a positive way the budgetary participation. In this way, the second hypothesis is about the influence of leadership style on the subordinate budget participation in budget activities: $\mathrm{H} 2$ - Leadership style is positively associated with budget participation.

According to Parker and Kyj (2006), subordinates who have an interactive dialogue with their superiors in the budget process can reveal important information about strategic uncertainties (Simons, 1995). Thus, budget information sharing provides subordinates with opportunities to share their perceptions with their superiors, thereby increasing the likelihood that the subordinate will communicate private information to his superiors (Covaleski et al., 2007; Parker \&Kyj, 2006).

The research by Kyj and Parker (2008) revealed a positive and significant association between the incentive to budget participation and the evaluation use of the budget, which suggests that in organizations that use the budget for this purpose, it may be more likely to observe this relationship, which reflects in the participation of the subordinates in the development of the budget of their units. In addition, when superiors promote and encourage subordinate participation in budgeting, they are more likely to actually participate and get involved in this process (Kyj\& Parker, 2008). In view of these findings, it is proposed in the third hypothesis of research, that there is an influence of the incentive to the budgetary participation on the budgetary participation of the subordinates: $\mathrm{H} 3$ - The incentive to the budgetary participation is positively associated to the budgetary participation.

The effect of budget participation on the performance of subordinates at work has been the subject of investigations in managerial (Chong et al., 2005) and behavioral accounting (Zonatto, 2014; Covaleski et al., 2007; Birnberg et al., 2006). Organizational theorists have predominantly evidence of a positive relationship between employee performance and participation in the budget (Covaleski et al., 2007; Lau, Low \&Eggleton, 1995), but the results are inconclusive (Shields, Deng \& Kato, 2000).

Budgetary participation has a positive effect on managerial performance, through motivational and cognitive mechanisms(Zonatto, 2014; Noor \& Othman, 2012; Covaleski et al., 2007; Birnberg et al.,2006; Parker \&Kyj, 2006; Shields \& Shields, 1998; Kren, 1992; Chenhall\& Brownell, 1988; Brownell, 1982). However, the study byAlmasi et al. (2015)and Etemadi et al. (2009)found a negative relationship between budgetary participation and managerial performance. In addition, there is also non-significant evidence of such a relationship (Macinati et al., 2016; Milani, 1975). For Lau and Tan (2005), Wentzel (2002), Shields and Shields (1998) and Mia (1988), the motivation for participation in budget processes increase subordinate confidence, control, ego involvement and their commitment to budget decisions, improving their managerial performance.

However, only participation is not able to ensure the achievement of better performance. Given the predominant evidence found in the literature, it is assumed that the participation of subordinates in the 
budget processes increases the level of managerial performance of these, which indicates a positive relationship between these variables. Thus, the fourth research hypothesis addresses the influence of subordinate participation on managerial performance: $\mathrm{H} 4$ - Budgetary participation is positively associated with managerial performance. However, this relationship can also occur indirectly through the intervening effects of vertical information sharing.

One of the most important benefits attributed to participatory budgeting is the sharing of information among members of the organization (Hopwood, 1976). In this sense, the reason for an organization to encourage budget participation is the sharing of information between superior and subordinate. Superiors can promote subordinate participation in order to obtain private information held by subordinates (Shields \& Shields, 1998). Thus, budget participation may provide an opportunity for subordinates to provide relevant information.

In this sense, budgetary participation makes it possible to improve the budget process as a whole, since superior and subordinate will share more information, which indicates a positive relationship between budget participation and vertical information sharing. The research developed by Jermias and Setiawan (2008) found that top management is often reluctant to share information with subordinates because they fear that they will misunderstand and misinterpret this information. However, the opposite may also occur in organizations (Kyj\& Parker, 2008; Shields \& Shields, 1998).Given these findings, the fifth hypothesis aims to evaluate the influence of budget participation on the sharing of vertical information. It is believed that under conditions of higher levels of budgetary participation, individuals are more likely to share information: $\mathrm{H} 5$ - Budget participation is positively associated with vertical information sharing.

Sharing vertical information can increase individuals' performance at work in a variety of ways (Parker \&Kyj, 2006), such as allowing the superior to help develop better strategies for developing budgets with the subordinate or ensuring that the subordinate receives adequate budget support (Nouri \& Parker, 1998). Nouri and Parker (1998) point out that the disclosure of private information maintained by subordinates and superiors may allow increased communication, which in turn has positive effects on the performance of subordinates at work in the budget context.According to Chenhall and Brownell (1988), the discussions with superiors during the budget processes allow clarifying the objectives and goals for the subordinates, being the sharing of relevant information in this process, since it has positive effects on the managerial performance of the subordinates.

Parker and Kyj (2006) presented evidence that vertical information sharing is an important mediating variable to understand the effects of budget participation on the subordinate's managerial performance. The authors have shown that vertical information sharing is positively associated with managerial performance. Thus, it is believed that the vertical information sharing influences in a positive way the performance of the controllers in the work. Thus, the sixth research hypothesis is about the influence of the vertical information sharing among the individuals of the organizations on the managerial performance: $\mathrm{H} 6$ - The vertical information sharing is positively associated to the managerial performance.

Figure 1 presents an overview of the theoretical model of analysis and the hypotheses tested in the study. 
Figure 1. Overview of the theoretical model of analysis and the research hypotheses

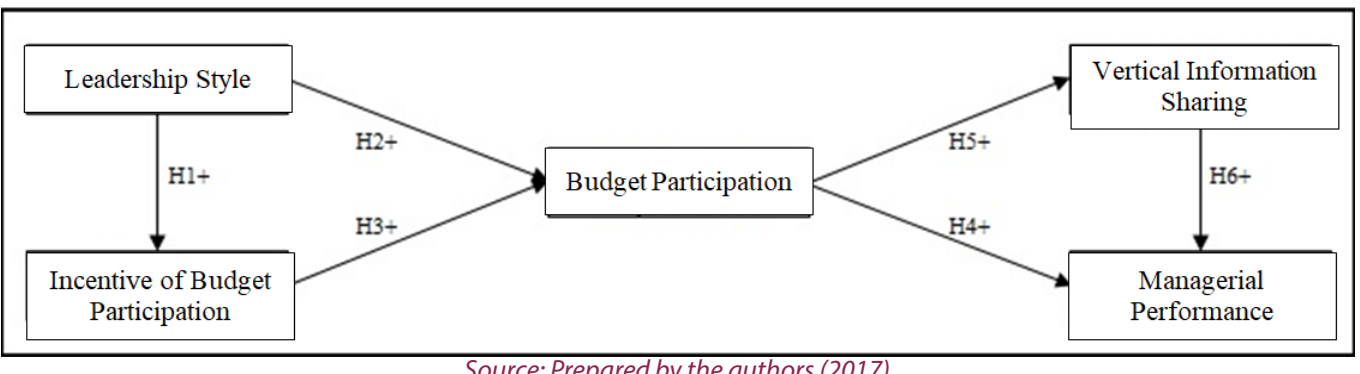

Source: Prepared by the authors (2017).

\section{METHOD AND RESEARCH PROCEDURES}

The methodology adopted in this research is characterized as a descriptive, survey and quantitative approach of the data, through the structural equation modeling technique. The population that is the object of this research consists of professionals responsible for the area of controlling companies that operate in Brazil, with budgetary responsibility. In a survey carried out with Linkedin business network, professionals with such characteristics were identified, with functions denominated as controllers, managers or coordinators of the controller.

These procedures are convergent to those adopted in other studies developed in the accounting area, which also analyzed managerial performance under the budget context with companies of different segments (Zonatto, 2014; Libby \& Lindsay, 2010; Kyj\& Parker, 2008; Chong et al.2005; Kren, 1992). In this study, controllers, managers and controllers of different organizations (62.66\% large companies) and sectors (industry, commerce, services and others) were used to conclude on the effects of budgetary participation on performance management of a specific group of Brazilian managers. However, it is recognized that the consideration of a specific group (managers with budgetary responsibilities) constitutes a limitation of the research.The analyzed sample is characterized as non-probabilistic, intentional and obtained by accessibility and counted on the voluntary participation of 316 controllers of different organizations based in the Country.

For the data collection, a questionnaire was elaborated, with objective questions, of multiple choice, which included self-assessments of the respondents. The Leadership Style (LS) variable was measured using an adapted version of the Leader Behavior Description Questionnaire (LBDQ, Form XII) developed by Stogdill (1963). The version used for the research instrument was adapted from the study by Kyj and Parker (2008), which contain five indicators. The variable Incentive to Participation of the subordinate in the Budget process (IBP) was adapted from the study of Kyj and Parker (2008) and is made up of three indicators.

To identify the variable Budgetary Participation (BP), the research instrument of Milani (1975) was adopted, which includes six questions. In order to measure the Managerial Performance (MP), the Mahoney, Jerdee and Carroll $(1965 ; 1963)$ self-assessment tool was used, in the version adapted by Zonatto (2014), which consists of nine indicators:planning, investigation, coordination, evaluation, supervision, selection, negotiation, representation and evaluation of overall performance in budget activities. The instrument to verify the intervening effects of the variable of Vertical Information Sharing (IS) was adapted from the study of Parker and Kyj (2006) and is composed of three indicators. 
The research tool used was developed in Google Docs and sent by e-mail to the managers participating in the research between the months of December 2016 and March 2017. The affirmative (assertive) questions on the researched topic had a seven-point Likert scale, which evaluated the level of agreement of the respondents, where the minimum disagreement level was 1 (Totally Disagree) and the maximum was 7 (Totally Agree).Because they cover questions of self-assessments of the respondents, the analyzed data may present a bias of responses, which may be a limitation of the research.However, it is believed that the methodological rigor adopted to carry out the research and the statistical treatment of the data, ensure discriminant validity of the analyzed constructs, which allows the inference on the relationships analyzed.

Prior to the application of the research instrument, translation and validation procedures were carried out by specialists, who were proficient in the English language, a research professor of the behavioral approach to accounting and a professional manager of the area of control. It was only after this evaluation and the pre-test with graduate students at the doctoral level, with professional experience in the area of control, that the data was collected.

The data collected were tabulated in electronic spreadsheets and imported into SPSS and AMOS software for statistical treatment. Initially, the descriptive statistical analysis of the variables was carried out, as well as the exploratory factorial analysis of the constructs, in order to investigate their adequacy. Finally, we analyzed the theoretical relations object of study, presented in Figure 1, through the modeling of structural equations. The criteria adopted for the validation of the measurement constructs were the indicators recommended by Hair Jr. et al. (2009), these being:Cronbach's Alpha (AC), Compound Validity (CV) and Extracted Variance (AVE). Table 1 presents the results of the discriminant validity and the adjustment indices of the structural model of measurement are presented in Table 2 . The results of the study are presented in the sequence.

\section{RESULTS PRESENTATION}

The results of the factorial analysis performed for all the constructs indicated that the KMO value is greater than 0.50 , which reveals the sample to be adequate to carry out the study. The results of the Bartlett sphericity tests were significant at the $5 \%$ level and the total variance explained went from $50 \%$ for all constructs. All the indicators reached minimum and maximum responses on the scale used, which indicates a degree of disagreement (1) or total agreement (7) in relation to the research questionnaires. The averages identified in the questionnaires are considered close, indicating agreement among the majority of the respondents. The results of the descriptive statistics also did not present great variations in the researched constructs. All indicators had factorial loads higher than 0.35 , minimum recommended by Hair Jr. et al. (2009), considering the sample size.

Based on the knowledge of various disciplines (economics, psychology and sociology), budget participation has been studied and explained due to a number of reasons, such as the need for information sharing, coordination of interdependencies among organizational subunits, and the increase of motivation and job satisfaction (Dani et al., 2017; Derfuss, 2016;Kyj\& Parker, 2008). In addition, it can allow subordinates to communicate private information regarding work to their superiors, resulting in a relationship that is more appropriate to the company's purposes, more assertive decision making and, consequently, a better managerial performance(Covaleski et al., 2007; Shields \& Shields, 1998; Nouri \& Parker, 1998;Magner et al., 1996). 
However, in the context of the performance of the controllers of organizations based in Brazil, such relations were not investigated, which is why these theoretical findings can only be confirmed or refuted through the following tests. Regarding the reliability indicators of the constructs, it was verified that all the constructs reached Cronbach's alpha coefficients above 0.4, Composite Validity greater than 0.86 and Extracted Variance higher than 0.5 . These results demonstrate the reliability of the measurement scales, which allows their validation and adequacy, as well as the evaluation of the structural models tested in this research. The same is true for the analysis of the discriminant validity of the constructs, as shown in Table 1.

Table 1. Results of the discriminant validity tests of the measurement constructs

\begin{tabular}{|c|c|c|c|c|c|}
\hline \multicolumn{6}{|c|}{ Correlation of the constructs with AVE } \\
\hline & LS & IBP & $\mathrm{BP}$ & IS & MP \\
\hline LS & 0,74 & & & & \\
\hline $\mathrm{IBP}$ & 0,38 & 0,72 & & & \\
\hline $\mathrm{BP}$ & 0,27 & 0,79 & 0,52 & & \\
\hline IS & 0,35 & 0,63 & 0,76 & 0,67 & \\
\hline MP & 0,18 & 0,38 & 0,42 & 0,61 & 0,50 \\
\hline \multicolumn{6}{|c|}{ Discriminant validity by the criterion of Fornell and Larcker (1981) } \\
\hline & LS & IBP & & PB & ISMP \\
\hline LS & 0,74 & & & & \\
\hline IBP & 0,15 & 0,72 & & & \\
\hline $\mathrm{BP}$ & 0,07 & 0,62 & 0,52 & & \\
\hline IS & 0,12 & 0,40 & 0,58 & 0,67 & \\
\hline MP & 0,03 & 0,14 & 0,17 & 0,38 & 0,50 \\
\hline \multicolumn{6}{|c|}{ Discriminant validity by the criterion of Bagozzi e Philips (1982) } \\
\hline \multicolumn{2}{|c|}{ PAR } & \multirow{2}{*}{$\begin{array}{l}\text { Constrained }(=1) \\
\text { Chi-Square }\end{array}$} & \multirow{2}{*}{$\begin{array}{l}\text { Notconstrained } \\
\text { Chi-Square }\end{array}$} & \multirow{2}{*}{$\begin{array}{l}\text { Differenceof } \\
\text { Chi-Square }\end{array}$} & \multirow{2}{*}{ Sig. } \\
\hline Construct A & Construct B & & & & \\
\hline $\mathrm{BP}$ & IS & 120,211 & 103,116 & 17,095 & 0,000 \\
\hline
\end{tabular}

Caption: LS. Leadership Style; IBP. Incentive to Budget Participation; BP. Budgetary Participation; IS. Information Sharing; MP. Management Performance.

Source: Research data (2017).

After the validation stage of the theoretical analysis constructs, it is then possible to evaluate the theoretical relations object of study. Initially, we proceeded to the structural modeling of the relationships presented in Figure 1. The results found revealed that the paths between leadership style and budget participation are not statistically significant. The same was observed in the path that investigates the direct relationship between participation and managerial performance. Thus, in order to test the consistency of such results, we proceeded to the modeling of a new structural model of analysis (purified), excluding the non-significant paths previously tested. The results found for the new model confirmed the significance of these relationships, which confirms these relationships. Table 2 presents the results of the adjustment indices of the structural models used in the research.

Table 2. Indices of adjustment of structural measurement models

\begin{tabular}{|l|l|l|l|}
\hline Indicator & Expectedvalue & InitialModel & Purified Final Model \\
\hline Chi2 & & 762,392 & 764,090 \\
\hline DegreeofFreedom & & 270 & 272 \\
\hline Chi2/DegreeofFreedom & $<5$ & 2,824 & 2,809 \\
\hline Statisticalsignificance & $\mathrm{p}<0,05$ & 0,000 & 0,000 \\
\hline Comparative Fit Index & $>0,90$ & 0,900 & 0,900 \\
\hline
\end{tabular}




\begin{tabular}{|l|l|l|l|}
\hline Tucker-Lewis Index & $>0,90$ & 0,889 & 0,890 \\
\hline Normed Fit Index & $>0,90$ & 0,854 & 0,853 \\
\hline Goodness of Fit Index & $>0,90$ & 0,829 & 0,829 \\
\hline GoodnessoffitQuality & $>0,90$ & 0,794 & 0,796 \\
\hline Root Mean Square Error of Approximation & $<0,10$ & 0,076 & 0,076 \\
\hline
\end{tabular}

Source: Research data (2017).

The results evidenced in Table 2 indicate that the proposed measurement models for the analysis of the influence of budget participation on vertical information sharing and managerial performance, observing the effects of variables antecedent to participation (leadership style and participation incentive), present acceptable values, close to those expected, which demonstrates the validity of the models. The adjustment index of these models presented a value of 2.824 (initial) and 2.809 (purified), both of which were significant at $p<0.000$. The mean squared approximation error values also reached adequate values (lower than 0.10), confirming the predictive quality of the results found for the relationships tested in these measurement models. Thus, it becomes possible to infer about such relationships.

\section{ANALYSIS AND DISCUSSION OF RESULTS}

Table 3 presents the standardized coefficients and significance of the relationships tested in both research models.

Table 3. Standardized coefficients and significance of the relationships of the tested models

\begin{tabular}{|c|c|c|c|c|c|c|c|c|}
\hline \multicolumn{9}{|c|}{ InitialModelResults } \\
\hline \multicolumn{3}{|c|}{ StructuralPathways } & \multirow{2}{*}{$\begin{array}{l}\text { Estimate } \\
1 \\
\end{array}$} & \multirow{2}{*}{$\begin{array}{ll}\text { E.P } \\
- \\
\end{array}$} & \multirow{2}{*}{$\mathrm{t}$ - values } & \multirow{2}{*}{$\rho$} & \multirow{2}{*}{$\begin{array}{l}\text { StandardizedCoefficient } \\
0,625\end{array}$} & \multirow{2}{*}{$\begin{array}{l}\mathrm{R} 2 \\
0,390 \\
\end{array}$} \\
\hline IBP & $<--$ & LS & & & & & & \\
\hline BP & $<--$ & IBP & 0,567 & 0,037 & 15,133 & $* * *$ & 0,873 & 0,726 \\
\hline BP & $<--$ & LS & $-0,035$ & 0,051 & $-0,697$ & 0,486 & $-0,034$ & 0,726 \\
\hline IS & $<--$ & $\mathrm{BP}$ & 0,852 & 0,058 & 14,707 & $* * *$ & 0,809 & 0,655 \\
\hline MP & $<--$ & $\mathrm{BP}$ & $-0,069$ & 0,065 & $-1,071$ & 0,284 & $-0,11$ & 0,414 \\
\hline MP & $<--$ & IS & 0,436 & 0,07 & 6,266 & $* * *$ & 0,729 & 0,414 \\
\hline \multicolumn{9}{|c|}{ Purified Final ModelResults } \\
\hline \multicolumn{3}{|c|}{ StructuralPathways } & Estimate & E.P & $\mathrm{t}$-values & $\rho$ & StandardizedCoefficient & R2 \\
\hline IBP & $\otimes$ & LS & 1 & - & - & - & 0,624 & 0,389 \\
\hline $\mathrm{BP}$ & $\otimes$ & IBP & 0,554 & 0,031 & 17,939 & 0,000 & 0,852 & 0,726 \\
\hline is & $\otimes$ & $\mathrm{BP}$ & 0,851 & 0,058 & 14,700 & 0,000 & 0,807 & 0,651 \\
\hline MP & $\otimes$ & IS & 0,383 & 0,041 & 9,446 & 0,000 & 0,639 & 0,408 \\
\hline
\end{tabular}

The relationship between the incentive to budget participation and the leadership style (IBP $\otimes L S$ ) presented an initial value set at 1.00 . Thus, the $t$-values of such relationships were not calculated. Note that all other relationships analyzed in the final purified model were significant at $1 \%$, which reveals that there are significant relationships between these constructs. It is observed direct effects of participation in the sharing of vertical information, and indirect participation in the managerial performance of controllers. In relation to the influence of the antecedents to the budgetary participation, it is perceived that the leadership style influences the incentive to participate,and exerts a direct influence on the budgetary participation.

These results show that the actions and behaviors of the leader are determinant to explain the budget configuration adopted by the companies and, in turn, the effects of this participation in the performance. Findings indicate that leaders with a friendly, accessible leadership style, who treat subor- 
dinates equally, who care about subordinate well-being, and explain actions to be developed clearly, are likely to promote participation of subordinates in the tasks related to the budget, encouraging these managers to participate in the budgetary processes of the organization, which confirms the first hypothesis investigated in the study: $\mathrm{H} 1$ : Leadership style is positively associated with the incentive to budget participation.

However, the findings indicated that the leader's style does not directly influence the participation of subordinates in the company's budget processes, results that do not support the second research hypothesis: H2: Leadership style is positively associated with budget participation. Despite these relationships, the results showed that the incentive to participate in the budget influences the participation of managers in the budget, which confirms the third hypothesis investigated in study H3: Incentive to the budgetary participation is positively associated with budget participation. Likewise, these findings indicate that leadership style influences budget participation indirectly, by encouraging budget participation.Previous research has shown that leadership style is evidenced as a precedent for budget participation since it can generate conflicts in organizations between subordinates and superiors (Baiman, 1990). Thus, leadership style may influence the incentive of budget participation in different ways. The studies conducted by Kyj and Parker (2008) and Brownell (1982) with managers with budgetary responsibilities corroborate with the results of this research since they also found a positive relationship between leadership style and the incentive to budget participation.This result is likely to occur in organizations from the moment the superiors respect their subordinates and develop actions based on trust and open communication, which consequently will have positive effects on budget participation(Kyj\& Parker, 2008; Fleishman \& Harris, 1962).

However, the results of this study disagree with the findings of Popli and Rizvi (2016),Otley and Pierce (1995) and Brownell (1983), as the authors showed a direct relationship between leadership style and budget participation, unlike that found in this search. This difference in outcome may have occurred due to the nature of the sample as well as the research tool used to measure leadership style and budget participation. Brownell (1983) surveyed mid-level managers with a cost center responsibilities of a large manufacturing firm and used Stogdill's original (1963) instrument to measure leadership style, which is composed of twenty different types of behaviors of leadership by the superior who are evaluated by subordinates. The study by Otley and Pierce (1995) analyzed this relationship with senior auditors of Big Six audit firms, based on the instrument developed by Pratt and Jiambalvo (1981), based on Stogdill (1963), which also addresses twenty leadership. Finally, Popli and Rizvi (2016) measured the transformational leadership style using the Multifactor Leadership Questionnaire(Bass \& Avolio, 1995; Bass, 1985). In the case of this research, the instrument of Kyj and Parker (2008), which covers five leadership behaviors of the twenty proposed by Stogdill (1963), was used, which may have disproved the relationship between leadership style and budget participation in this research.In addition, a specific style of leadership was not analyzed, such as the Popli and Rizvi (2016) research, which analyzed the transformational leadership style.

Therefore, the role of the leader and his/her leadership styles are very important for reaching the goals (Kasiati, Minarsih\&Warso, 2015), and subordinate participation in the budget context is seen as a key strategy for organizational success (Popli\&Rizvl, 2016). On the other hand, the research developed by Kyj and Parker (2008) also did not reveal a direct relationship between the style of leadership and the participation in the budget. 
This evidence reinforcesthe importance of investigating the effects of budgetary participation from a broader theoretical perspective, observing the effects of variables antecedent to participation, capable of explaining the budget configuration adopted by companies and their effects on attitudes, behaviors and in managerial performance.

Concerning the incentive to budget participation and budget participation, it is noted that the theoretical predictions developed in the literature from empirical studies confirm in this research that the incentive to participate presents positive results in relation to the budget participation. Thus, it can be inferred that, under these conditions, superiors and their subordinates will be more likely to present a more interactive dialogue during the budget process(Covaleski et al., 2007; Parker \&Kyj, 2006).Therefor, the greater the incentive for the subordinate to participate and become involved in the budget context, the greater will be his / her participation in the budgeting activities of his units (Kyj\& Parker, 2008). Consequently, it is expected that therewill be greater sharing of information and performanceat work.

Analyzing the direct influence of the managers' participation in the budget activities, in the managerial performance, it is possible to identify that this relation is not significant, which suggests that in this model its influence occurs indirectly, mediated by the sharing of vertical information occurred in the budget process. Thus, this result does not support the confirmation of the fourth research hypothesis: $\mathrm{H} 4$ : Budget participation is positively associated with managerial performance.

This result differsfrom the findings of Etemadi et al. (2009) for a sample of mid-level managers of industries listed on the Tehran Stock Exchange andAlmasi et al. (2015) to the context of mid-level managers of a Teheran Regional Electricity Company. It can be observed from this result that the Brazilian reality differs from the Islamic context, since the two evidence of a negative relation found in the literature, by these authors, comes from studies realized out in the capital of Iran.Considering this negative relation, but without significance in this research, Almasi et al.(2015) recommendations that the superiors improve the participation rate of the managers in the budget processes, analyze the proposals of alteration of the budget, making that the participation of the managers in the budgetary processes helps in the budgetary adjustments, and that superiors seek suggestions, ideas, and demands from managers, with a view to improving their participation in the budgeting of their units. In addition, they indicate that indirect effects may occur in this relationship, which in turn improves participation and performance.

Analyzing the influence of the direct effects of the budget participation in the vertical information sharing and of this variable in the managerial performance, it is possible to affirm that the budgetary participation of the individuals participating in the research influences the vertical information sharing in the organization, which confirms the fifth hypothesis $\mathrm{H} 5$ : Budgetary participation is positively associated with vertical information sharing.Likewise, it can be inferred that in conditions of higher levels of budgetary participation, managers are more likely to share vertical information, which, in this research, positively influenced the managerial performance of the controllers participating in the study, confirming the sixth research hypothesis: $\mathrm{H6}$-Vertical information sharing is positively associated with managerial performance.

These results corroborate with the findings of the studies developed by Parker and Kyj (2006) and Shields and Shields (1998), both studies carried out with managers in the budget context in the United States, which indicates that the Brazilian reality resembles the reality of the Parker and Kyj (2006) and Shields and Shields (1998), as they also found positive relationships for such relationships. From these results, Shields and Shields (1998) point out that one of the important reasons for the existence 
of budgetary participation is the sharing of information between superior and his subordinates, as evidenced in this research.

Thus, budgeting gives subordinates opportunities to share their perceptions with their superiors, thereby increasing the likelihood that the subordinate will communicate private information to his superiors(Covaleski et al., 2007; Parker \&Kyj, 2006; Shields \& Shields, 1998).In this sense, budget participation provides important opportunities for information sharing between superior and his subordinates and vice versa (Kyj and Parker, 2008; Shields \& Shields, 1998). Hopwood (1976) points out that the sharing of vertical information is one of the most relevant benefits of individuals' participation in the budget context. However, as emphasized by Jermias and Setiawan (2008), superiors often do not share information with subordinates because they fear that they will manipulate and misinterpret information, which would explain the conflicting results found for the direct relation of participation to performance.

It is noted that information sharing can increase job performance by allowing the superior to develop better strategies relative to subordinate budgets as well as ensuring that the subordinate receives adequate budget support(Parker \&Kyj, 2006; Nouri \& Parker, 1998).This positive relationship shows that the sharing of information between the superior and the subordinate facilitates the loyalty and trust of the employees in the management of the organization, thus promoting greater cooperation and flexibility at all managerial levels (Mia \&Patiar, 2002).

The results obtained byNouri and Parker (1998),Penno (1984) and Baiman and Evans (1983), demonstrated that budget participation allows subordinates to reveal more information that can lead to greater managerial performance and also, for the organization. The research by Chenhall and Brownell (1988) also revealed that discussions that occur during budgeting processes may allow managers to clarify budget goals and targets. Thus, the constraints of such participation effects are related to the sharing of relevant information in this process and not just participation. These studies support the evidence found in this research.

Considering the set of results found in this research, it is verified that, although such evidence suggests that budget participation results in greater vertical information sharing, the findings provide indications that the effects of budgetary participation on managerial performance do not occur directly. These effects are mediated by the sharing of vertical information, which reinforces the informational roles of the budget, a cognitive element that constitutes an important intervening variable for the understanding of the conditions in which a greater budgetary participation results in a better managerial performance of the controllers.

These results are observed when the leaders of these organizations are more likely to encourage the participation of these professionals in the budget processes, which suggests that the actions of the leader will indicate the condition in which the participation of the managers will occur. Consequently, they end up influencing the actions of controllers in this process, the level of vertical information sharing and performance.These findings reinforce the need to investigate such relationship (budget participation vs. managerial performance) from a broader and integrated theoretical perspective, so that one can better understand the constraints of the results of this relationship, which has sometimes been pointed out as conflicting in the literature accounting(Dani et al., 2017; Derfuss, 2016).

In summary, the results revealed that the greater the participation of the controllers of companies based in Brazil, in the budgetary processes of organizations, the greater the tendency is to share vertical information between the superior and the subordinate, and the greater tends to be their managerial 
performance, results that confirm the informational roles of the budget, constituted as cognitive effects of budgetary participation.

\section{FINAL CONSIDERATIONS}

The results of the research contribute to the existing literature and have significant theoretical and managerial implications. As theoretical contributions, initially, the findings revealed that the way the leader conducts his work reflects on the participation of individuals in the budget processes since this is the main responsible for encouraging the subordinates to participate in this process. This relationship is strengthened through the leader's encouragement for subordinates to participate in budget decisions and to become more involved in the budget context.

Thus, as subordinates are more encouraged to participate in the budget processes, consequently there will be frequent and possibly more extensive discussions between superiors and their subordinates (Covaleski et al., 2007; Parker \&Kyj, 2006;Milani, 1975); as well as, there may be greater disclosure of relevant information about the strategic uncertainties of organizations (Simons, 1995). This result is convergent to those found by Kyj and Parker (2008), indicating the importance of understanding the effects of variables antecedent to participation, which explain their consequent effects on the behavior of individuals.

Another theoretical contribution is the observation that one of the reasons for the existence of budget participation and the involvement of subordinates in this process is the sharing of vertical information since the budget participation provides a greater sharing of information and consequently a better performance in budget activities.More specifically, it has been shown that budget participation reinforces information sharing, suggesting that increasing organizational support through budget participation provides information that supports controllers' belief that they have the capacity and resources to carry out management tasks, together with their superiors.

As managerial implications, it should be noted that although there are good reasons to believe in the power of accounting practices to promote managerial performance, their impact on the sharing of information and performance at work, as well as the consideration of factors antecedent to participation, provides a additional reason to recommend to the organizations a high involvement of managers in budget processes.In this way, the results obtained in this research can be applied in the budget context, to support the role of managers, developing initiatives that strengthen the leadership style, which increase the incentive to the budget participation of these professionals, and, in turn, their work performance. This suggests that organizations that aim to improve the performance of controllers should focus on organizational practices that provide greater involvement in an internal environment rich in information that can be shared, such as the budget context.

In addition, this study contributes to the superiors of organizations to pay attention to the benefits of individual participation in budget processes, as this participation may result in the disclosure of information that is important for the financial and managerial health of organizations, success in front of its competitors and, above all, better internal operation.Therefore, these results corroborate with the evidence of the direct and indirect effects of the budget on controllers actions in the budget context, as well as indicate how their use may result in better budget forecasts, greater involvement of these professionals in the work and the obtaining better performance at work.

The results of this research are subject to some limitations, being specific to the analyzed sampleand research instrument used. However, they reveal important interactions between the variables studied, 
which can serve as a starting point for new investigations related to professionals with controller assignments.Previous studies have evaluated sample groups that considered managers and accountants in general and not specifically controllers of the area of control, as is the case of this research.

Thus, the findings provide indications of variables that influence the actions of a specific group of managers in the budget context (controllers), about which there is still little evidence of behavioral variables that influence the relationship between budget participation and their performance at work. Studies developed on the behavioral approach to accounting have used several variables in their investigation, whether these are related to the antecedents of participation or to the elements consequent to it, which can be used to carry out future studies so that one can understand their interactions about an specific group of managers.Such opportunities encourage further studies.

\section{REFERENCES}

Almasi, H., Palizdar, M. R., \&Parsian, H. (2015). Budgetary participation and managerial performance: The impact of information and environmental volatility. Management Science Letters5, 843-854.DOI: https://ssrn.com/abstract=2633506

Argyris, C. (1952). Diagnosing defenses against the outsider. Journal of Social Issues, 8(3), 24-34.DOI: https://doi.org/10.1111/j.1540-4560.1952.tb01615.x

Bagozzi, R. P., \& Phillips, L. W. (1982). Representing and testing organizational theories: A holistic construal. Administrative science Quarterly, 27(3), 459-489.DOI: 10.2307/2392322

Baiman, S., \& Evans, J. H. (1983). Pre-decision information and participative management control systems. Journal of Accounting Research,21(2), 371-395.DOI: 10.2307/2490780

Baiman, S. (1990). Agency Research in Managerial Accounting', Accounting, Organizations and Society, 15(4), 341-371.DOI: https://doi.org/10.1016/0361-3682(90)90023-N

Bass, B.M. (1985). Leadership and performance beyond expectation. New York, NY: Free Press.

Bass, B.M., \& Avolio, B. (1995). MLQ Multifactor Leadership Questionnaire. Redwood City, CA: Mind Garden.

Bianchi, E. M. P. G.,Quishida, A.,\&Foroni, P. G. (2017). A Leader's Role in Strategic People Management: Reflections, Gaps and Opportunities. Revista de Administração Contemporânea, 21(1), 41-61.DOI: http:// dx.doi.org/10.1590/1982-7849rac2017150280

Birnberg, J. G.,Luft, J., \& Shields, M. D. (2007). Psychology theory in management accounting research. In. Chapman, C. S.; Hopwood, A. G.; Shields, M. D. Handbook of Management Accounting Research, 1(4), 113-135.DOI: https://doi.org/10.1016/S1751-3243(06)01004-2

Brownell, P. (1982). The role of accounting data in performance evaluation, budgetary participation, and organizational effectiveness. Journal of Accounting Research, 20(1),12-27.DOI: 10.2307/2490760

Brownell, P. (1983). Leadership style, budgetary participation and managerial behavior. Accounting, Organizations and Society, 8(4), 307-321.DOI: https://doi.org/10.2307/2490760

Chenhall, R. H., \& Brownell, P. (1988). The effect of participative budgeting on job satisfaction and performance: Role ambiguity as an intervening variable. Accounting, Organizations and Society, 13(3), 225-233.DOI: https://doi.org/10.1016/0361-3682(88)90001-3 
Chong, V. K., Eggleton, I. R. C.,\&Leong, M. K. C. (2005). The impact of market competition and budgetary participation on performance and job satisfaction: a research note. The British Accounting Review, 37(1), 115-133.DOl: https://doi.org/10.1016/j.bar.2004.06.007

Covaleski, M., Evans III, J. H., Luft, J. L., \& Shields, M. D. (2007). Budgeting research: three theoretical perspectives and criteria for selective integration. Handbooks of Management Accounting Research, 2(6), 587-624.DOI: https://doi.org/10.2308/jmar.2003.15.1.3

Dani, A. C., Zonatto, V. C. S., \& Diehl, C. A. (2017). Participação orçamentária e desempenho gerencial: uma meta-análise das relações encontradas em pesquisas desenvolvidas na área comportamental da contabilidade. Advances in Scientific and Applied Accounting, 10(1), 54-72.DOI: 10.14392/ASAA.2017100104

Derfuss, K. (2016). Reconsidering the participative budgeting-performance relation: A meta-analysis regarding the impact of level of analysis, sample selection, measurement, and industry influences. The British Accounting Review, 48(1), 17-37.DOI: https://doi.org/10.1016/j.bar.2015.07.001

Etemadi, H., Dilami, Z. D., Bazaz, M. S., \&Parameswaran, R. (2009). Culture, management accounting and managerial performance: Focus Iran. Advances in Accounting, Incorporating Advances inInternational Accounting, 25(2), 216-225.DOI: https://doi.org/10.1016/j.adiac.2009.08.005

Fleishman, E. A., \& Harris, E. F. (1962). Patterns of leadership behavior related to employee grievances and turnover. Personnel Psychology, 15(1), 43-56.DOI: https://doi.org/10.1111/j.1744-6570.1962.tb01845.x

Fleishman, E. A., \& Peters, D. R. (1962). Interpersonal values, leadership attitudes, and managerial "success". Personnel Psychology, 15(2), 127-143.DOI: https://doi.org/10.1111/j.1744-6570.1962.tb01855.x

Fornell, C., \& Larcker, D. F. (1981). Structural equation models with unobservable variables and measurement error: Algebra and statistics. Journal of Marketing Research, 18(3), 382-388.DOI: https://doi. org/10.2307/3150980

Hopwood, A. G. (1976). Accounting and Human Behavior.Englewood Cliffs, NJ: Prentice Hall.

Jermias, J., \& Setiawan, T. (2008). The moderating effects of hierarchy and control systems on the relationship between budgetary participation and performance. The International Journal of Accounting, 43(3), 268-292.DOI: https://doi.org/10.1016/j.intacc.2008.06.009

Kasiati, M., Minarsih, M.\&Warso, M. (2015). Effect Of Leadership Style, Internal Communication and Cultural Organization of The Department of Transportation District Employee Performance Puncak Jaya. Journal of Management, 1(1), 1-14.

Kren, L. (1992). (1992). Budgetary participation and managerial performance: The impact of information and environmental volatility. Accounting Review, 67(3), 511-526. DOl: https://www.jstor.org/ stable/247975

Kyj, L., \& Parker, R. J. (2008). Antecedents of budget participation: leadership style, information asymmetry, and evaluative use of budget. Abacus, 44(4), 423-442.DOI: https://doi.org/10.1111/j. 1467-6281.2008.00270.x

Lau, C. M., \& Tan, S. L. (2005). The importance of procedural fairness in budgeting. Advances in Accounting, 21, 333-356.DOI: https://doi.org/10.1016/S0882-6110(05)21014-3

Lau, C. M., Low, L. C., \& Eggleton, I. R. (1995). The impact of reliance on accounting performance measures on job-related tension and managerial performance: additional evidence. Accounting, Organizations and Society, 20(5), 359-381.DOI: https://doi.org/10.1016/0361-3682(94)00031-P

Libby, T., \& Lindsay, R. M. (2010). Beyond budgeting or budgeting reconsidered? A survey of North-American budgeting practice. Management Accounting Research, 21(1), 56-75.DOI: https://doi. org/10.1016/j.mar.2009.10.003 
Locke, E., \& Latham, G. (1990). A Theory of Goal Setting G Task Performunce. Englewood Cliffs, NJ: Prentice-Hail.

Macinati, M. S., Bozzi, S., \& Rizzo, M. G. (2016). Budgetary participation and performance: The mediating effects of medical managers' job engagement and self-efficacy. Health Policy, 120(9), 1017-1028.DOI: https://doi.org/10.1016/j.healthpol.2016.08.005

Magner, N., Welker, R. B., \& Campbell, T. L. (1996). Testing a model of cognitive budgetary participation processes in a latent variable structural equations framework. Accounting and Business Research, 27(1), 41-50.DOI: https://doi.org/10.1080/00014788.1996.9729530

Mahoney, T. A., Jerdee, T. H., \& Carroll, S. J. (1963). Development of Managerial Performance: A Research Approach. Cincinnati, $\mathrm{OH}$ : South-Western Publishing.

Mahoney, T. A., Jerdee, T. H., \& Carroll, S. J. (1965). The job(s) of management. Industrial Relations, 4(2), 97-110.DOI: https://doi.org/10.1111/j.1468-232X.1965.tb00922.x

Mia, L. (1988). Managerial attitude, motivation and the effectiveness of budget participation. Accounting, Organizations and Society, 13(5), 465-475.DOI: https://doi.org/10.1016/0361-3682(88)90017-7

Mia, L., \& Patiar, A. (2002). The interactive effect of superior-subordinate relationship and budget participation on managerial performance in the hotel industry: an exploratory study. Journal of Hospitality \& Tourism Research, 26(3), 235-257.DOI: https://doi.org/10.1177/1096348002026003003

Milani, K. (1975). The relationship of participation in budget-setting to industrial supervisor performance and attitudes: a field study. The Accounting Review, 50(2), 274-284. DOI: https://www.jstor.org/ stable/244709

Niemeyer, J. R. L.,\&Cavazotte, F.de S. C. N.(2016). Ethical leadership, leader-follower relationship and performance: a study in a telecommunications company. Revista de Administração Mackenzie, 17(2), 67-92.DOI: http://dx.doi.org/10.1590/1678-69712016/administracao.v17n2p67-92

Noor, I. H. B. M., \& Othman, R. (2012). Budgetary participation: How it affects performance and commitment. Accountancy Business and the Public Interest, 1, 53-73.DOl: https://ssrn.com/abstract=2161688

Nouri, H., \& Parker, R. J. (1998). The relationship between budget participation and job performance: the roles of budget adequacy and organizational commitment. Accounting, Organizations and Society,23(5-6), 467-483.DOI: https://doi.org/10.1016/S0361-3682(97)00036-6

Otley, D. T., \& Pierce, B. J. (1995). The control problem in public accounting firms: An empirical study of the impact of leadership style. Accounting, Organizations and Society, 20(5), 405-420.DOI: https://doi. org/10.1016/0361-3682(95)00003-R

Parker, R. J., \& Kyj, L. (2006). Vertical information sharing in the budgeting process. Accounting, Organizations and Society, 31(1), 27-45.DOI: https://doi.org/10.1016/j.aos.2004.07.005

Pearce, C. L., Conger, J. A., \& Locke, E. A. (2008). Shared leadership theory. The Leadership Quarterly, 19(5), 622-628.DOI: https://doi.org/10.1016/j.leaqua.2008.07.005

Penno, M. (1984). Asymmetry of pre-decision information and managerial accounting. Journal of Accounting Research, 22(1), 177-191.DOI: 10.2307/2490707

Popli, S., \&Rizvi, I. A. (2016). Drivers of employee engagement: The role of leadership style. Global Business Review, 17(4), 965-979.DOI: https://doi.org/10.1177/0972150916645701

Pratt, J. \&Jiambalvo, J. (1981). Relationships between Leader Behaviors and Audit Team Performance. Accounting, Organizations and Society, 6(2), 132-142.DOI: https://doi.org/10.1016/0361-3682(81)90003-9 
Shields, M. D., Deng, F. J., \& Kato, Y. (2000). The design and effects of control systems: tests of direct-and indirect-effects models. Accounting, Organizations and Society, 25(2), 185-202.DOI: https://doi. org/10.1016/S0361-3682(99)00041-0

Shields, J. F., \& Shields, M. D. (1998). Antecedents of participative budgeting. Accounting, Organizations and Society, 23(1), 49-76.DOI: https://doi.org/10.1016/S0361-3682(97)00014-7

Shields, M. D., \& Young, S. M. (1993). Antecedents and consequences of participative budgeting: evidence on the effects of asymmetrical information. Journal of Management Accounting Research,5, 265.

Silva, A. F. S. da., \& Gomes, J. S. (2011). Consideração do Elemento Cultural no Desenho de Sistemas de Controle de Gestão das Empresas Estrangeiras: Estudo de Casos. Contabilidade Vista \&Revista, 22(1), 143-176.

Simons, R. (1995). Control in an age of empowerment. Harvard Business Review, 73(2), 80-88.

Stogdill, R. M. (1963). Manual for the leader behavior description questionnaire-Form XII: An experimental revision. Bureau of Business Research, College of Commerce and Administration, Ohio State University.

Webb, R. A. (2002). The impact of reputation and variance investigations on the creation of budget slack. Accounting, Organizations and Society, 27(4), 361-378.DOI: https://doi.org/10.1016/S03613682(01)00034-4

Wentzel, K. (2002). The influence of fairness perceptions and goal commitment on managers' performance in a budget setting. Behavioral Research In Accounting, 14, 247-271.DOI: https://doi. org/10.2308/bria.2002.14.1.247

Wong-On-Wing, B., Guo, L., \& Lui, G. (2010). Intrinsic and extrinsic motivation and participation in budgeting: Antecedents and consequences. BehavioralResearch in Accounting, 22(2), 133-153.DOI: https://doi.org/10.2308/bria.2010.22.2.133

Zonatto, V. C. da S. (2014). Influência de fatores sociais cognitivos de capacidade, vontade e oportunidade sobre o desempenho gerencial nas atividades orçamentárias das maiores empresas exportadoras do Brasil. 2014. 412 f, Tese (Doutorado) - Universidade Regional de Blumenau, Programa de Pós-Graduação em Ciências Contábeis e Administração.

\section{APPENDIX}

Questionnaire

Leadership Style

The statements below are related to the identification of the "Leadership Style" of the managers participating in the survey. Please indicate the extent to which you disagree with or agree with the statements below. The degree of agreement varies between (1) totally disagree and (7) strongly agree.

1. My immediate supervisor is friendly and approachable.

2. My immediate supervisor treats his/her subordinates as his/her equals.

3. My immediate supervisor looks out for the personal welfare of subordinates.

4. My immediate supervisor explains his/her actions to subordinates.

5. My immediate supervisor acts without consulting his/her subordinates. (reverse wording) 
Incentive of (Subordinate) Budget Participation

The following statements are related to the identification of the "Incentive of Budget Participation" of the company in which it operates. Please indicate how much you disagree with or agree with the statements. The degree of agreement varies between (1) totally disagree and (7) strongly agree.

1. My immediate supervisor strongly encourages me to participate in the budget setting process.

2. My immediate supervisor actively seeks my input in the budget setting process.

3. In the budgeting process, my supervisor seems to seek my input more than the input of his/her other subordinates.

\section{Budget Participation}

The statements below are related to the managers and their in the "Budgetary Participation" of the company in which it operates. Please indicate the extent to which you disagree with or agree with the statements below. The degree of agreement varies between (1) totally disagree and (7) strongly agree.

1. The portion of the budget I am involved in setting.

2. The amount of reasoning provided to me by a superior when the budget is revised.

3. The frequency of budget-related discussions with superiors initiated by me.

4. The amount of influence I feel I have on the final budget.

5. The importance of my contribution to the budget.

6. The frequency of budget-related discussion initiated by my superior when budgets are being set.

Information Sharing

The statements below are related to "Information Sharing" in the company in which it operates. Please indicate the extent to which you disagree with or agree with the statements below. The degree of agreement varies between (1) totally disagree and (7) strongly agree. In the budget process:

1. I share my insights with my superior about the situation in my area of responsibility.

2. I communicate information to my superiors about opportunities and problems facing the organization.

3. Information is shared with superiors who help remedy problems in the organization (for example, to learn about better ways to do activities).

\section{Managerial Performance}

The following statements are related to the identification of the "managerial performance in the work activities" of the managers participating in the research. Please self-evaluate your performance comparatively to your peers, based on each of the activities (tasks) specified below. The self assessment scale ranges from [1] below-average performance [7] to above-average performance.

1. Determining goals, policies, and courses of action (e.g., work scheduling, budgeting, programming).

2. Collecting and preparing information, usually in the form of records, reports, and accounts (e.g., measuring output, record keeping, job analysis). 
3. Exchanging information with people in the organization other than your subordinates in order to relate and adjust programs (e.g., expediting, liaison with other managers, arranging meetings).

4. Assessment and appraisal of proposals or reported/observed performance (e.g., employee appraisals, judging output records, product inspection).

5. Directing, leading, and developing your subordinates.

6. Maintaining the work force of your unit (e.g., selecting and promoting employees).

7. Purchasing, selling, or contracting for goods and services (e.g., tax negotiations,contracting with suppliers, collective bargaining, advertising).

8. Advancing the general interests of my organization through speeches, consultation, or contact with others outside the organization.

9. How do you evaluate your overall performance?

Article related to the Project "Research on managerial performance of managers with budgetary responsibility" (Process: 472195 / 2014- 